\title{
Antibacterial Activity of Ethanolic Extracts of Lentinus squarrosulus Mont. against Human Pathogenic Bacteria
}

\author{
Waraporn Sutthisa* (D) and Phaninyada Chaiyacham \\ Department of Biology, Faculty of Science, Mahasarakham University, \\ Kantarawichai District, Maha Sarakham Province, 44150 Thailand.
}

\begin{abstract}
Lentinus squarrosulus (Mont.) is a wide edible mushroom widely consumed in Thailand. Ethanol extract was extracted from mycelium of $L$. squarrosulus No. 2 and Lentinus basidiocarp obtained from the local market at Mahasarakham province using $50 \%$ ethanol solvent. The effect of ethanolic extracts was tested for inhibition to some pathogenic bacteria. Antibacterial activity was tested by Poison food technique, it was found that $\mathbf{5 0} \%$ ethanol extract from mycelium at concentrations of $10 \%, 15 \%$, and $30 \%$ was effective to inhibit Bacillus cereus at the highest level (+++) and mycelium extract at the concentrations of $15 \%$ and $30 \%$ can inhibit Staphylococcus aureus with low level $(+)$. But all concentrations of $L$. squarrosulus basidiocarp extract unable to inhibit the growth of $B$. cereus, Escherichia coli, Pseudomonas aeruginosa and S. aureus. Minimal inhibitory concentration (MIC) and minimal bactericidal concentration (MBC) of ethanolic extract from mycelium inhibit $B$. cereus was $125 \mathrm{mg} / \mathrm{ml}$. The results indicate that the potential of $L$. squarrosulus mycelium is an excellent source of antimicrobial agents.
\end{abstract}

Keywords: Ethanolic extract, Lentinus squarrosulus, Minimal inhibitory concentration (MIC)

\footnotetext{
*Correspondence: waraporn.s@msu.ac.th

(Received: September 14, 2021; accepted: January 18, 2022)

Citation: Sutthisa W, Chaiyacham P. Antibacterial Activity of Ethanolic Extracts of Lentinus squarrosulus Mont. against Human Pathogenic Bacteria. J Pure App/ Microbiol. 2022;16(1)441-447. doi: 10.22207/JPAM.16.1.41

(C) The Author(s) 2022. Open Access. This article is distributed under the terms of the Creative Commons Attribution 4.0 International License which permits unrestricted use, sharing, distribution, and reproduction in any medium, provided you give appropriate credit to the original author(s) and the source, provide a link to the Creative Commons license, and indicate if changes were made.
} 


\section{INTRODUCTION}

The tropical macrofungi Lentinus squarrosulus (Mont.) were classified in the family Polyporaceae. The wild-edible mushroom L. squarrosulus is commonly found and widely consumed in Asia. This fungus grows on rotted logs and is usually found in the rainy season between April and October each year. In the north and northeastern region of Thailand people widely consumed $L$. squarrosulus..$^{1-6} L$. squarrosulus has various remarkable characters including mycelium growth rapidly and having the capacity to become a food, and a food supplement. The basidiocarp and mycelium of this mushroom is rich in nutrients and minerals that are beneficial to humans. ${ }^{4,7}$ Mushrooms accumulate a variety of secondary metabolites which have many beneficial biological properties especially the antimicrobial effect. ${ }^{7}$ Microorganisms produce secondary metabolites, most of which have antimicrobial properties. ${ }^{8}$ Several studies have been reported on the production of secondary metabolites from Lentinus spp., such as a tetrahydrofuran derivative from L. squarrosulus BCC $22366 .{ }^{5}$ The antimicrobial compound lanthionine and its derivative have been isolated from basidiocarp and mycelia of Lentinula edodes can inhibit some bacteria and fungi. ${ }^{9}$ Bioactivity screening of the secondary extracts of $L$. squarrosulus mushroom extracted with dichloromethane and the antimicrobial activity of this extract was assessed by agar diffusion method. From the experimental results, it was found that secondary metabolites of $L$. squarrosulus extracted with dichloromethane solvent were inhibited the growth of Escherichia coli, Enterobacter aerogenes, Staphylococcus aureus, and Bacillus subtilis. ${ }^{10}$ Basidiocarp of $L$. squarrosulus was extracted with aqueous and alcohol solvent show antibacterial activity against Gram-positive and Gram-negative bacteria. ${ }^{11}$ The minimum inhibitory concentration (MIC) of the extracts ranged from 50 to $75 \mathrm{mg} / \mathrm{disc}^{12}$ Rajalingam ${ }^{13}$ assessed the antibacterial activity of a combination of dichloromethane and methanol extract of $L$. squarrosulus that grew on rice. The results show that $L$. squarrosulus mycelial extracts present various degrees of inhibitory effect against microbe growth. ${ }^{14}$

The mechanism of antibacterial activity is related to the generation of reactive oxygen species. ${ }^{2}$
Lentinus edodes extracts with various solvents (acetone, ethyl acetate, and ethanol) investigated the antimicrobial activities. Antimicrobial activities of the extracts were determined against $B$. subtilis, S. aureus, Micrococcus luteus, E. coli, Pseudomonas aeruginosa, and $E$. cloacae by the disc diffusion method. The results show that acetone and ethanol extract present moderate antibacterial activities with almost all tested microorganisms except $E$. coli and $S$. aureus while extraction with ethyl acetate solvent shows antibacterial activity viz. E. coli, E. cloacae, and B. subtilis. ${ }^{15}$ The antimicrobial activity of Russula vesca, Auricularia auricular, Pleurotus squarrosulus, and Volvariaella vulvae extracted with ethanol, hot and cold extract was studied against some Gram-negative bacteria (E. coli, P. aeruginosa, Klebsiella pneumoniae, Proteus mirabilis, Salmonella typhi) and Grampositive bacteria (Bacillus cereus, S. aureus, Streptococcus pneumoniae). Each mushroom extract was evaluated with the minimum inhibitory concentrations (MIC). $R$. vesca hot water extracts can inhibit the growth of E. coli, S. typhi, and $P$. mirabilis. While $A$. auricular ethanol extract has a wide antibacterial activity but cannot inhibit the growth of $S$. typhi and $P$. aeruginosa. Cold water extract of most mushroom species obtained bioactive substances less than ethanol and hot water extracts. ${ }^{16}$ Study the antimicrobial activity of methanolic extract of $L$. squarrosulus on B. cereus, B. subtilis, S. aureus, P. vulgaris, $P$. aeruginosa and E. coli the minimum inhibitory concentration (MIC) of the extracts was $50,50,75,75,50,50$ and 50 $\mu \mathrm{g} /$ disc, respectively. ${ }^{12}$

Currently, major problem of the world is development of antibiotic resistance of pathogenic bacteria. The alternative option is to find biological extracts that can inhibit the growth of those bacteria. Therefore, this research aimed to study the efficacy of $50 \%$ ethanol extract of mycelium and basidiocarp of $L$. squarrosulus on inhibition to pathogenic bacteria as an alternative for applications in the future.

\section{MATERIALS AND METHODS \\ Samples preparation}

Fresh L. squarrosulus basidiocarp obtained from local markets in Mahasarakham province rinsed thoroughly with distilled water, then cut it into small pieces (both the pileus and 
stipes) and oven-dried at $50^{\circ} \mathrm{C}$ overnight and then store at $4^{\circ} \mathrm{C}$ until tested.

Stock culture of L. squarrosulus (No. 2) obtained from the Department of Agriculture, Thailand, and maintained on potato dextrose agar (PDA) slant. Preparation of $L$. squarrosulus inoculum by subculture on PDA for 7 days. Then three mycelium plugs cut from the edge of the colony subculture into $100 \mathrm{~mL}$ Erlenmeyer flasks containing sterile yeast malt extract broth (YMB) media. Incubation at static conditions for 18 days at $30^{\circ} \mathrm{C}$. Mushroom mycelium was collected by filtering through a sterile sheet cloth and then rinse twice with distilled $\mathrm{H}_{2} \mathrm{O}$ to remove the media and oven-dried at $50^{\circ} \mathrm{C}$ for $3 \mathrm{hr}$ and then store at $4^{\circ} \mathrm{C}$ until tested.

\section{Preparation of extracts}

The dried basidiocarp or mycelia of $L$. squarrosulus ( $50 \mathrm{~g}$ ) were extracted twice with 450 $\mathrm{ml}$ of $50 \%$ ethanol at $100^{\circ} \mathrm{C}$ for $3 \mathrm{hr}$ in a water bath. The dried basidiocarp or mycelia of $L$. squarrosulus (50 g) were extracted twice with $450 \mathrm{ml}$ of $50 \%$ ethanol at $100^{\circ} \mathrm{C}$ for $3 \mathrm{hr}$ in a water bath. Because the ethanol solvent polarity was influenced by the high concentration of water contained in ethanol. The more water contained in it, the higher its polarity compared to absolute ethanol. Solvents with high polarity had the ability to extract a class of compounds with a wider polarity. ${ }^{17}$ After that extracted at room temperature for $1 \mathrm{hr}$ in sonicate bath, and then shaken at $150 \mathrm{rpm}$ for $24 \mathrm{hr}$. The extract was filtered using filter paper (Whatman No. 1) and the ethanol was removed using a rotary evaporator. They were then dried using a freeze dryer and stored at $-4^{\circ} \mathrm{C}$ for further analysis.

\section{Bacterial strains and inoculum preparation}

Bacterial strains used in this study include Gram-negative Escherichia coli and Pseudomonas aeruginosa and Gram-positive Bacillus cereus and Staphylococus aureus were procured from the Microbiology Laboratory, Department of Biology, Faculty of Science, Mahasarakham University, Thailand. They were grown on nutrient agar (NA) at $37^{\circ} \mathrm{C}$ for $18-24 \mathrm{hr}$. The cell suspensions were then prepared with a density of $1.5 \times 10^{8} \mathrm{CFU} / \mathrm{ml}$ (0.5 McFarland standard).

Determination of antibacterial activity by poisoned food technique

The antibacterial activity of ethanolic extracts of $\mathrm{t}$ of $L$. squarrosulus against $E$. coli,
$P$. aeruginosa, $B$. cereus, and $S$. aureus was evaluated by using the poison food technique. The extract was dissolved in sterile distilled water to a final concentration of $250 \mathrm{mg} / \mathrm{ml}$ (100\%). Sterilized NA medium was amended with different concentrations of $L$. squarrosulus extracts (10\%, $15 \%$, and $30 \%$ ) then poured into $90 \mathrm{~mm}$ Petri plates at $20 \mathrm{ml} /$ plate and distilled $\mathrm{H}_{2} \mathrm{O}$ was used as negative control which was introduced into NA medium instead of mushroom extract. Let the surface of the medium dry then drop $5 \mu$ l of testing pathogen cell suspension $\left(1.5 \times 10^{8} \mathrm{CFU} / \mathrm{ml}\right)$ onto the surface of the medium and streaked in parallel $4 \mathrm{~cm}$ long. Three replications were maintained for each treatment. All the plates were incubated at $37^{\circ} \mathrm{C}$ for $24-48 \mathrm{hr}$ for bacterial growth and was evaluated as follows: (-) no inhibition, (+) slightly inhibited, $(++)$ moderately inhibited, $(+++)$ strong inhibited.

\section{Minimal inhibitory concentration (MIC)}

The minimum inhibitory concentration (MIC) of ethanolic extracts of the mushrooms was established like the Clinical and Laboratory Standards Institute protocol. ${ }^{18}$ The MIC of the extracts was determined for the test organisms at varying concentrations $125,62.5,31.25,15.62$, $7.80,3.90,1.95,0.98,0.49$, and $0.25 \mathrm{mg} / \mathrm{ml}$ of the extract were added to the 96- well microtiter plates. Next, each well was inoculated with 100 $\mu \mathrm{l}$ of $10^{8} \mathrm{CFU} / \mathrm{ml}$ testing microorganisms ( $E$. coli, P. aeruginosa, B. cereus and S. aureus). 100 $\mu l$ of Mueller Hinton Broth (MHB) without the mushroom extract was set up as the negative control, and $100 \mu \mathrm{l}$ of $250 \mathrm{mg} / \mathrm{ml}$ streptomycin were set up as the positive control. All the bacterial cultures were incubated at $37^{\circ} \mathrm{C}$ for $24 \mathrm{hr}$ after that each plate was determined by measuring the optical density (OD) at $600 \mathrm{~nm}$ by using Multimode Plate Reader. The MIC value was determined from the lowest concentration of the extract that inhibited the growth of test microorganisms.

\section{Minimal bactericidal concentration (MBC)}

The minimum bactericidal concentration (MBC) was determined by selecting wells from 96 wells plate that did not show bacterial growth from the MIC test. A loopful from each of the wells was sub-cultured on the NA medium and incubated at $37^{\circ} \mathrm{C}$ for $24 \mathrm{hr}$. When there was no colony growth from the directly plated contents of the wells, it is considered an $\mathrm{MBC}$ value. 


\section{RESULTS}

Determination of antibacterial activity by poisoned food technique

Study on the effect of ethanolic extracts of $L$. squarrosulus on the growth of pathogenic bacteria tested by poison food technique. The results showed that at concentrations of $10 \%$, $15 \%$ and $30 \%$ of $L$. squarrosulus mycelium extract inhibited the growth of $B$. cereus with the highest levels (+++) and extract at $15 \%$ and $30 \%$ showed a slight inhibition of S. aureus at low levels + (Fig. 1, Table 1). All concentrations of mycelium and basidiocarp extract tested did not inhibit the growth of $P$. aeruginosa and $E$. coli. In addition, it was found that $30 \%$ of mycelium extract as a

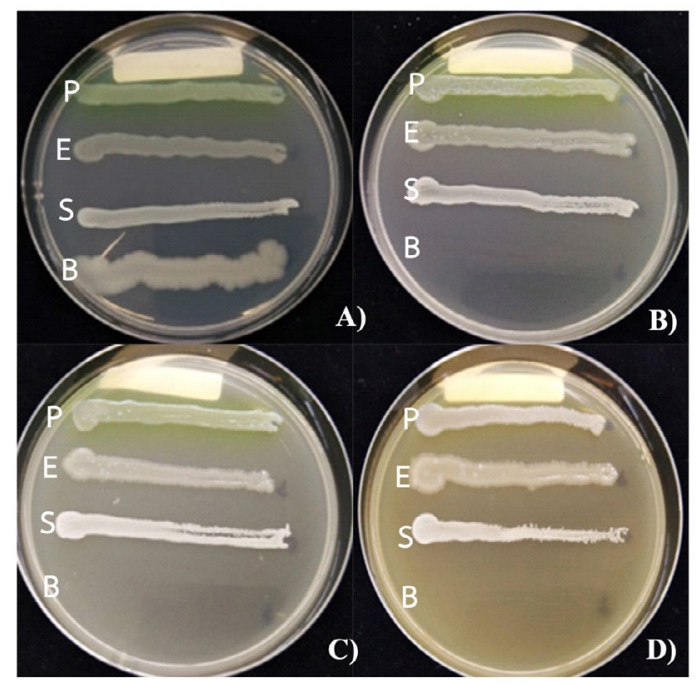

Fig. 1. Effect of $50 \%$ ethanol extract of $L$. squarrosulus mycelium on inhibition to pathogenic bacteria. A) Control, B) $30 \%$ mycelium extract, C) $15 \%$ mycelium extract, D) $10 \%$ mycelium extract, $\mathrm{P}=P$. aeruginosa, $\mathrm{E}$ $=E$. coli, $\mathrm{S}=\mathrm{S}$. aureus, $\mathrm{B}=\mathrm{B}$. cereus. result, the colony characteristics of $P$. aeruginosa were changed, without fluorescence pigment production compared with the control. In this study, we found that all concentrations of $50 \%$ ethanol extract from $L$. squarrosulus basidiocarp were not inhibited the growth of $E$. coli, $P$. aeruginosa, B. cereus and S. aureus.

\section{Minimal inhibitory concentration (MIC)}

Evaluation of the minimum inhibitory concentration (MIC) of $50 \%$ ethanol extract of $L$. squarrosulus mycelium against $B$. cereus was studied. It was found that the lowest concentration of the extract capable of inhibiting $B$. cereus was $125 \mathrm{mg} / \mathrm{ml}$ (Fig. 2). The growth rate was measured by turbidity measurement with a microwell plate reader with a wavelength of $600 \mathrm{~nm}$. It was shown that when the extract concentration decreased, the extract efficiency in inhibiting pathogenic bacteria decreased.

Minimal bactericidal concentration (MBC)

When taken to find the minimal bactericidal concentration (MBC) found that at a concentration of $125 \mathrm{mg} / \mathrm{ml} \mathrm{50 \%}$ ethanol extract of $L$. squarrosulus mycelium can destroy B. cereus, while at other concentrations it can grow (Fig. 3).

\section{DISCUSSION}

Mushrooms are an important food that is rich in nutrition. There are also many important substances, including secondary metabolites that have antimicrobial properties. One of these mushrooms is $L$. squarrosulus found in many parts of Asia including Thailand. It has been proven that $L$. squarrosulus has certain antimicrobial properties against various pathogenic bacteria. ${ }^{19}$ In this research we extract the mycelium and basidiocarp of $L$. squarrosulus with $50 \%$ ethanol

Table 1. Effect of $50 \%$ ethanol extract of $L$. squarrosulus mycelium on inhibition to pathogenic bacteria

\begin{tabular}{|c|c|c|c|c|c|c|c|c|}
\hline \multirow{2}{*}{$\begin{array}{l}\% \text { mushroom } \\
\text { extract }\end{array}$} & \multicolumn{4}{|c|}{ Mycelium extracts ${ }^{1} /$} & \multicolumn{4}{|c|}{ Basidiocarp extracts } \\
\hline & $\begin{array}{c}P . \\
\text { aeruginosa }\end{array}$ & $\begin{array}{l}E . \\
\text { coli }\end{array}$ & $\begin{array}{c}\text { S. } \\
\text { aureus }\end{array}$ & $\begin{array}{c}B . \\
\text { cereus }\end{array}$ & $\begin{array}{c}P . \\
\text { aeruginosa }\end{array}$ & $\begin{array}{l}E . \\
\text { coli }\end{array}$ & $\begin{array}{c}\text { S. } \\
\text { aureus }\end{array}$ & $\begin{array}{c}\text { B. } \\
\text { cereus }\end{array}$ \\
\hline 30 & - & - & + & +++ & - & - & - & - \\
\hline 15 & - & - & + & +++ & - & - & - & - \\
\hline 10 & - & - & - & +++ & - & - & - & - \\
\hline 0 & - & - & - & - & - & - & - & - \\
\hline
\end{tabular}

1/ - no inhibition, + slightly inhibited, ++ moderately inhibited, +++ strong inhibited. 
extract yielded an initial concentration of the extract of $250 \mathrm{mg} / \mathrm{ml}$. While Boonsong et al. ${ }^{20}$ extracted $L$. edodes with $50 \%$ ethanol and analyzed for active substances. The highest phenolic compounds were found to be about $24.25 \mathrm{mg} / \mathrm{g}$ and flavonoids were $1.64 \mathrm{mg} / \mathrm{g}$. The effect of ethanolic extract of $L$. squarrosulus on the growth of pathogenic bacteria was tested by the poison food technique. It was found that $10 \%, 15 \%$, and $30 \%$ of mycelium extract completely inhibiting the growth of $B$. cereus and slightly inhibiting the growth of $S$. aureus, both bacteria were Grampositive. While the $L$. squarrosulus basidiocarp extract was not able to inhibit the growth of test bacteria in this study. Gram-negative bacteria tested were not affected by ethanolic extract of $L$. squarrosulus mycelium and basidiocarp. Similarly,
Soliman and El-Sayed ${ }^{21}$ evaluated for antimicrobial activity of ethanolic extracts from wild mushrooms against various pathogens. Screening of the antimicrobial activity against Gram-positive, Gramnegative bacteria, and the yeast of the ethanolic wild mushroom extracts showed that Agrocybe aegerita, Chlorophyllum molybdites, and Lentinus squarrosulus had little activity against pathogenic bacteria and yeast examined. While Gram-positive bacteria were more sensitive to the ethanolic extracts of Bjerkandera adusta and Cyclocybe cylindracea than Gram-negative bacteria.

Evaluation of the minimum inhibitory concentration (MIC) of mycelium ethanol extract viz.B. cereus was made. It was found that the lowest concentration of the extract capable of inhibiting B. cereus was $125 \mathrm{mg} / \mathrm{ml}$. When the concentration

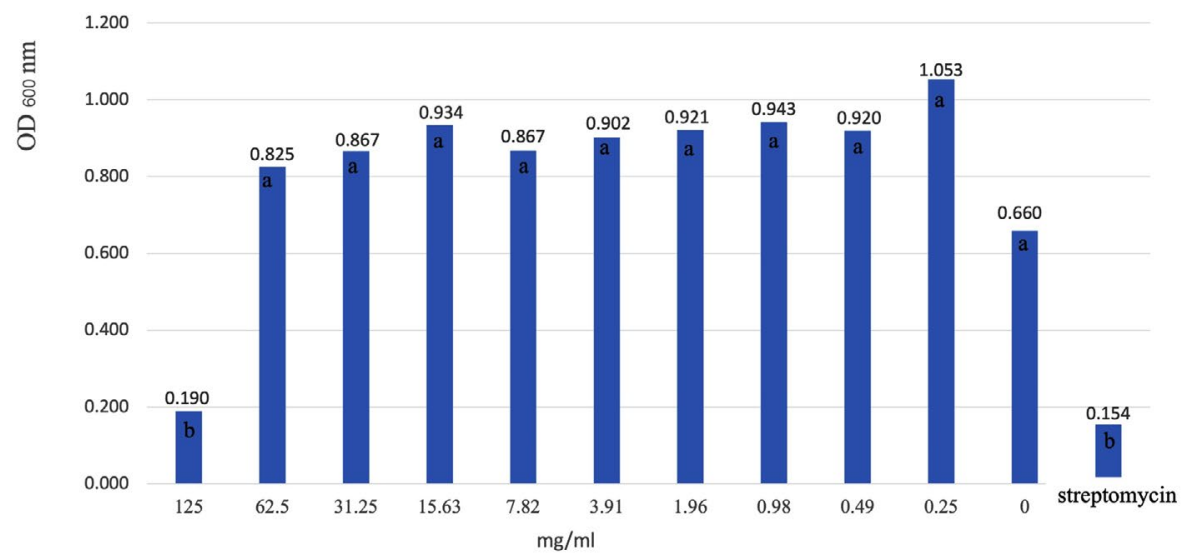

Fig. 2. Minimum inhibitory concentration (MIC) of $50 \%$ ethanol extract of $L$. squarrosulus mycelium to inhibit $B$. cereus. Means with different letters are significantly different by least significant difference test $(P \leq 0.01)$.

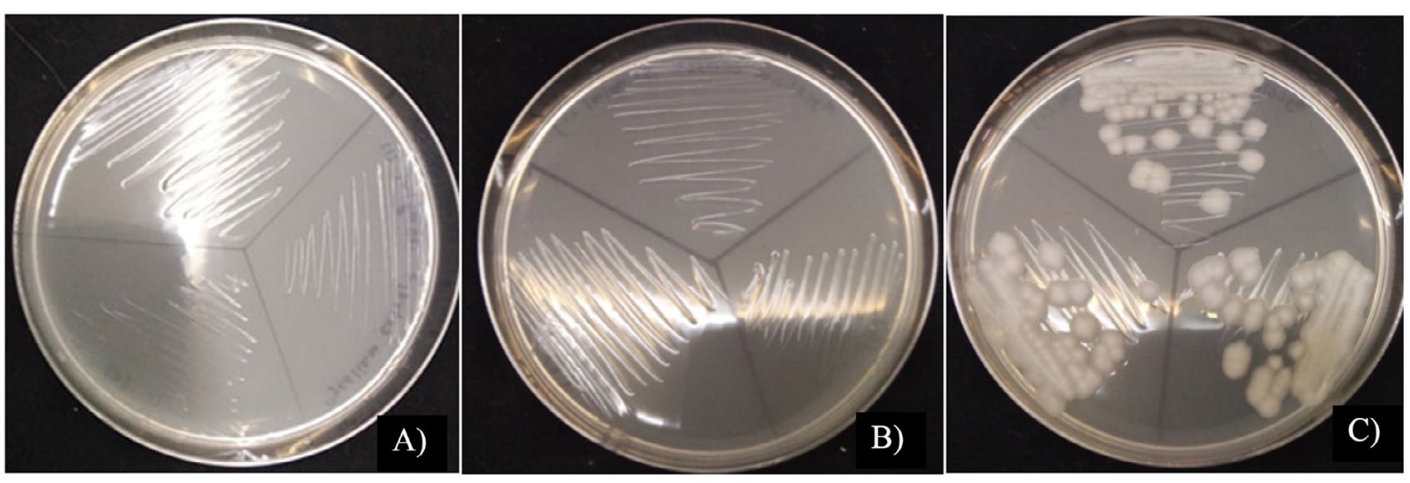

Fig. 3. Minimal bactericidal concentration (MBC) of $50 \%$ ethanol extract of $L$. squarrosulus mycelium to destroyed Bacillus cereus. A) Streptomycin $250 \mathrm{mg} / \mathrm{ml} \mathrm{B)} 125 \mathrm{mg} / \mathrm{ml}$ ethanol extract of $L$. squarrosulus mycelium C) $62.5 \mathrm{mg} /$ $\mathrm{ml}$ ethanol extract of $L$. squarrosulus mycelium. 
of the extract was reduced, bacterial growth was found to be increased by measuring the growth rate by measuring the turbidity with a microwell plate reader (OD600 nm). When determining the minimal bactericidal concentration $(\mathrm{MBC})$, it was found that the minimum destroys concentration of $B$. cereus was $125 \mathrm{mg} / \mathrm{ml}$. Similarly, Pascua et al. ${ }^{22}$ determine the antibacterial activity of L. squarrosulus using the disc diffusion method against S. aureus (ATCC 29213) and E. coli (ATCC 25992). The results revealed that $L$. squarrosulus exhibited antibacterial activity versus $E$. coli (ATCC 25992) and S. aureus (ATCC 29213). Methanolic extract of edible mushrooms $L$. squarrosulus was investigated for its antimicrobial activity. It was found that methanolic extracts of the basidiocarps of $L$. squarrosulus showed degree of antimicrobial activity against the test organisms including $S$. aureus, B. cereus, B. subtilis, P. vulgaris, E. coli, and $P$. aeruginosa. ${ }^{14}$ The MIC of $L$. squarrosulus methanolic extract was $50 \mathrm{ug} / \mathrm{disc}$. The filtrates of $L$. squarrosulus showed wider inhibition zones of $16.2 \mathrm{~mm}$ for $S$. aureus and $18.6 \mathrm{~mm}$ for $E$. coli. ${ }^{23}$ Investigation of antibacterial activity of the edible mushroom extract against foodborne pathogenic bacteria viz. B. cereus, En. aerogenes, E. coli, Micrococcus luteus, P. vulgaris, Salmonella typhimurium and $S$. aureus. Flammulina velutipes, Ganoderma lucidum, Pleurotus ostreatus, and Pleurotus pulmonarius extracts show inhibitory effects on bacteria. Only P. pulmonarius extracted with water was effective against all bacteria tested. The minimum inhibitory concentrations (MIC) of ethyl acetate extract of $F$. velutipes and $P$. pulmonarius, methanol extract of $G$. lucidum, and the water extract of $P$. pulmonarius show 12.5-22.5 $\mathrm{mg} / \mathrm{ml} \mathrm{MIC}$ against $B$. cereus and $12.5-22.5 \mathrm{mg} /$ $\mathrm{ml} \mathrm{MIC}$ against $S$. typhimurium. ${ }^{24}$ L. squarrosulus crude extracts were investigated antibacterial activities against 11 bacteria species. It was found that gram-negative bacteria were less susceptible to crude extract than gram-positive bacteria with a higher MIC value. ${ }^{25}$ This research concluded that Gram-positive bacteria were more sensitive to the ethanol extract from the mycelium of $L$. squarrosulus than Gram-negative bacteria. While basidiocarp extract unable to inhibit all tested bacteria.

\section{ACKNOWLEDGMENTS}

The authors would like to thank the Department of Biology, Faculty of Science, Mahasarakham University, Thailand for the support of research equipment and grateful to Dr. Adrian Roderick Plant for English language editing.

\section{CONFLICT OF INTEREST}

The authors declares that there is no conflict of interest.

\section{AUTHORS' CONTRIBUTION}

Both the authors listed have made a substantial, direct and intellectual contribution to the work, and approved it for publication.

\section{FUNDING}

None.

\section{DATA AVAILABILITY}

All datasets generated or analyzed during this study are included in the manuscript.

\section{ETHICS STATEMENT}

This article does not contain any studies with human participants or animals performed by any of the authors.

\section{REFERENCES}

1. De Leon AM, Guinto LJZG, De Ramos PDV, Kalaw SP. Enriched cultivation of Lentinus squarrosulus (Mont.) Singer: A newly domesticated wild edible mushroom in the Philippines. Mycosphere. 2017;8(3):615-629. doi: $10.5943 /$ mycosphere/8/3/9

2. Lau BF, Abdullah N. Bioprospecting of Lentinus squarrosulus Mont., an underutilized wild edible mushroom, as a potential source of functional ingredients: A review. Trends in Food Science \& Technology. 2017;61:116-131. doi: 10.1016/j. tifs.2016.11.017

3. Adeoye-Isijola MO, Olajuyigbe OO, Jonathan SG, Coopoosamy RM. Bioactive compounds in ethanol extract of Lentinus squarrosulus Mont a Nigerian medicinal macro fungus. Afr J Tradit Complement Altern Med. 2018;15(2):42-50. doi: 10.21010/ ajtcamv15i2.6

4. Omar NAM, Abdullah N, Kuppusamy UR, Abdulla MA, Sabaratnam V. Nutritional composition, antioxidant activities, and antiulcer potential of Lentinus squarrosulus (Mont.) mycelia extract. Evid Based Complement Alternat Med. 2011;2011:539356. doi: 10.1155/2011/539356 
5. Isaka M, Palasarn S, Sappan M, Srichomthong K, Karunarathna SC, Hyde KD. Prenylhydroquinonederived secondary metabolites from cultures of the basidiomycete Lentinus simili sBCC 52578 . Nat Prod Commun. 2015;10(8):1391-1393. doi: 10.1177\%2F1934578X1501000820

6. Ahmad R, Muniandy S, Shukri NIA, et al. Antioxidant properties and glucan compositions of various crude extract from Lentinus squarrosulus mycelial culture. Adv Biosci Biotechnol. 2014;5(10):805-814. doi: 10.4236/abb.2014.510094

7. Jiamworanunkul S. Effective antioxidant production through submerged fermentation of edible mushrooms. Thai Journal of Pharmaceutical Sciences. 2019;43 (4):213-218.

8. Sukmawati, Angraini E, Angraeni DN, Umami SS, Sumiati E, Taufiqurokhman T. Antagonism of Lentinuscladopus Lc4 extract, Trichoderma sp. Jpaextract on Bacillus sp., Xanthomonas sp. and E. Coli. J Phys: Conf Ser. 2019;1155:012057. doi: 10.1088/1742-6596/1155/1/012057

9. Kwak AM, Lee IK, Lee SY, Yun BS, Kang HW. Oxalic acid from Lentinula edodes culture filtrate: antimicrobial activity on phytopathogenic bacteria and qualitative and quantitative analyses. Mycobiology. 2016;44(4):338342. doi: 10.5941/MYCO.2016.44.4.338

10. Usha N, Shashikanth S, Janardhana GR. Structural elucidation of novel bioactive compound (2-chloro1-(2-chlorocyclopropyl)-2-(4-nitrophenyl) ethanone) from basidiomycetous fungus Lentinus squarrosulus. International Journal of Pharmacological Research. 2016;6(02):62-67. doi: 10.7439/ijpr

11. Borokini F, Lajide L, Olaleye T, Boligon A, Athayde $M$, Adesina I. Chemical profile and antimicrobial activities of two edible mushrooms (Termitomyces robustus and Lentinus squarrosulus). I Microbiol Biotechnol Food Sci. 2016;5(5):416-423. doi: 10.15414/ jmbfs.2016.5.5.416-423

12. Giri S, Biswas G, Pradhan P, Mandal SC, Acharya K. Antimicrobial activities of basidiocarps of wild edible mushrooms of West Bengal, India. International Journal of Pharm Tech Research. 2012;4(4):1554-1560.

13. Reyes NL, Kalaw SP, De Leon AM. Antioxidant screening, teratogenicity and antifungal property of Lentinus squarrosulus (Mont.) Singer. Asian Journal of Biochemical and Pharmaceutical Research. 2016;6:122-134.

14. Manna DK, Mandal AK, Sen IK, et al. Antibacterial and DNA degradation potential of silver nano- particles synthesized via green route. Int J Biol Macromol. 2015;80:455-459. doi: 10.1016/j.ijbiomac.2015.07.028

15. Han SR, Kim MJ, Oh TJ. Antioxidant activities and antimicrobial effects of solvent extracts from Lentinus edodes. Journal of the Korean Society of Food Science and Nutrition. 2015;44(8):1144-1149. doi: 10.3746/ jkfn.2015.44.8.1144

16. Nwachukwu E, Uzoeto HO. Antimicrobial activity of some local mushrooms on pathogenic isolates. Journal of Medicinal Plants Research. 2010;4(23):2460-2465. doi: 10.5897/JMPR10.154

17. Hikmawanti NPE, Fatmawati S, Asri AW. The effect of ethanol concentrations as the extraction solvent on antioxidant activity of Katuk (Sauropus androgynus (L.) Merr.) leaves extracts. IOP Conf Ser: Earth Environ Sci. 2020;755:012060. doi: 10.1088/17551315/755/1/012060

18. Clinical and Laboratory Standards Institute. Method for dilution antimicrobial susceptibility teste for bacterial that grow aerobically. In: 11ed Edition. Clinical and Laboratory Standards M07. West Valley Road, Suite 1400, Wayne, Pennsylvania 19087- 1898 USA. 2018. https://clsi.org/media/1928/m07ed11_sample.pdf.

19. Ugbogu EA, Akubugwo IE, Ude VC, Gilbert J, Ekeanyanwu B. Toxicological evaluation of phytochemical characterized aqueous extract of wild dried Lentinus squarrosulus (Mont.) mushroom in rats. Toxicological Research. 2019;35(2):181-190. doi: 10.5487/TR.2019.35.2.181

20. Boonsong S, Klaypradit W, Wilaipun P. Antioxidant activities of extracts from five edible mushrooms using different extractants. Agriculture and Natural Resources. 2016;50(2):89-97. doi: 10.1016/j. anres.2015.07.002

21. Soliman ERS, El-Sayed H. Molecular identification and antimicrobial activities of some wild Egyptian mushrooms: Bjerkandera adusta as a promising source of bioactive antimicrobial phenolic compounds. Journal of Genetic Engineering and Biotechnology. 2021;19(1):106. doi: 10.1186/s43141-021-00200-8

22. Pascua SM, Kalaw PS, De Leon AM. Proximate composition, mycochemical analysis and antibacterial activity of Lentinus squarrosulus (Mont.) Singer. Advances in Environmental Biology. 2016;10(3):58-68.

23. Ayodele SM, Idoko ME. Antimicrobial activities of four wild edible mushrooms in Nigeria. International Journal of Science and Nature. 2011;2(1):55-58.

24. Chaiharn M, Phutdhawong WS, Amornlerdpison D, Phutdhawong W. Antibacterial, antioxidant properties and bioactive compounds of Thai cultivated mushroom extracts against food-borne bacterial strains. Chiang Mai Journal of Sciences. 2018;45(4):1713-1727.

25. Mossebo DC, Metsebing BP, Oba R, et al. Comparative evaluation of antifungal and antibacterial activities of crude extracts of Pleurotussajor-caju, Pleurotus tuberregiumand Lentinus squarrosulus (Basidiomycota, Pleurotaceae, Lentinaceae) from Cameroon. European Journal of Biology and Biotechnology. 2020;1(5):1-7. doi: 10.24018/ejbio.2020.1.5.97 